\title{
ANALISIS HUBUNGAN KINERJA KEUANGAN BERDASAR AKUNTANSI DAN KINERJA KEUANGAN BERDASAR PASAR PADA PERUSAHAAN YANG TERDAFTAR DI JAKARTA ISLAMIC INDEX (JII) DENGAN PENGUNGKAPAN CSR SEBAGAI VARIABEL MODERASI
}

\author{
Nanda Putri Angelia ${ }^{1)}$, Sinarti, S.E., M.Sc., Akt ${ }^{2}$ \\ Jurusan Manajemen Bisnis, Politeknik Neheri Batam \\ Jl. Ahmad Yani, Batam Centre, Batam 29461, Indonesia \\ 1) E-mail: nandaputriangelia@gmail.com \\ ${ }^{2)}$ E-mail: sinar@polibatam.ac.id
}

\begin{abstract}
Abstrak
Penelitian ini bertujuan untuk menguji dan memberikan bukti empiris mengenai adanya pengaruh kinerja keuangan berdasar akuntansi yang diukur dengan Return On Assets (ROA), Return On Equity (ROE), dan Economic Value Added (EVA) terhadap kinerja keuangan berdasar pasar yang diukur dengan return saham Ketidakkonsistenan hasil penelitian mengenai pengaruh kinerja keuangan berdasar akuntansi yang diukur dengan ROA, ROE, dan EVA terhadap return saham mengindikasikan adanya variabel moderasi yang berpengaruh yaitu pengungkapan Corporate Social Responsibilty (CSR). Pengungkapan CSR diharapkan dapat memberikan sinyal kepada pihak eksternal termasuk investor dalam meningkatkan citra perusahaan yang tercermin dengan peningkatan return saham sehingga penelitian ini juga menggunakan CSR sebagai variabel moderasi. Sampel penelitian adalah sebanyak 19 perusahaan yang terdaftar di Jakarta Islamic Index (JII) selama tahun 2008-2013 dengan jumlah observasi sebanyak 95 data perusahaan. Pengumpulan data dilakukan dengan metode purposive sampling dan hipotesis diuji dengan analisis regresi data panel dan uji nilai selisih mutlak. Hasil penelitian menunjukkan bahwa kinerja keuangan berdasar akuntansi yang diukur dengan ROA, ROE, dan EVA berpengaruh terhadap kinerja keuangan berdasar pasar yang diukur dengan return saham. Sedangkan pengungkapan CSR dalam laporan tahunan perusahaan tidak memoderasi pengaruh kinerja keuangan berdasar akuntansi dengan kinerja keuangan berdasar pasar.
\end{abstract}

Kata Kunci: Kinerja keuangan berdasar akuntansi, Kinerja keuangan berdasar pasar, Corporate Social Responsibility 


\begin{abstract}
The objectives of this research are to test and to give empiric evident about influence between financial performance based on accounting which measured by Return On Assets (ROA), Return On Equity (ROE), and Economic Value Added (EVA) and financial performance based on marketplace which measured by stock return. The inconsistency of the result of researches on the influence of financial performance based on accounting to financial performance based on marketplace indicated there is moderate variable that influence the disclosure of Corporate Social Responsibilty (CSR). CSR disclosure is expected to give a signal to external parties including investors in enhancing the corporate image is reflected by increase of stock returns. There are 19 companies that are taken as the sample in this research. The object of this research is companies that listed in Jakarta Islamic Index (JII) from 2008-2013 with 95 data observation. Data are collected by using purposive sampling. Hypotheses in this research are tested using panel data regression and test of absolute difference value. The result of this research showed that financial performance based on accounting which measured by ROA, ROE, and EVA influenced to financial performance based on marketplace which measured by stock return. Meanwhile CSR disclosure in annual company report is not moderating financial performance based on accounting to financial performance based on marketplace.
\end{abstract}

Keywords: Financial performance based on accounting, financial performance based on marketplace, Corporate Social Responsibility (CSR). 


\section{Pendahuluan}

Secara umum tujuan utama suatu perusahaan adalah untuk memperoleh laba yang maksimal, tidak hanya laba akuntansi tapi juga laba ekonomi. Salah satu alternatif yang dilakukan perusahaan agar dapat mencapai tujuannya adalah dengan meningkatkan aktivitas operasional perusahaan. Untuk meningkatkan operasional perusahaan dibutuhkan modal yang besar, namun terkadang hal ini menjadi keterbatasan bagi sebagian besar perusahaan. Pasar modal merupakan sebuah wadah yang mempunyai peran penting dalam perekonomian. Perkembangan pasar modal di Indonesia semakin pesat, dilihat dari semakin banyaknya perusahaan yang terdaftar di Bursa Efek Indonesia (BEI) dan meningkatnya minat masyarakat untuk berinvestasi. Berdasarkan penelitian yang dilakukan oleh [8] menunjukkan bahwa perkembangan investasi di Indonesia dalam kurun waktu 5 (lima) tahun terakhir selalu meningkat secara kuantitas. Perusahaan yang membutuhkan modal sangat banyak, sementara investor terbatas sehingga investor akan memilih perusahaan yang memiliki kinerja keuangan yang baik untuk berinvestasi karena tujuan utama seorang investor melakukan investasi adalah untuk memperoleh keuntungan baik berbentuk modal (capital gain) atau dividen jika berinvestasi pada saham [4].

Pengukuran kinerja keuangan perusahaan dapat diukur dengan beberapa pendekatan, dua diantaranya yaitu pengukuran kinerja keuangan berdasar akuntansi dan pengukuran kinerja keuangan berdasar pasar yang diukur dengan return saham. Analisis laporan keuangan yang banyak dilakukan perusahaan untuk mengukur kinerja keuangan berdasar akuntansinya adalah dengan menggunakan metode konvensional yaitu analisis rasio keuangan. Analisis rasio keuangan yang umum digunakan dalam penelitian pengukuran kinerja keuangan adalah Return On Assets (ROA) dan Return On Equity (ROE) yang dihubungkan dengan return saham. Tahun 1993 perusahaan Stern Stewart \& Co mengembangkan konsep Economic Value Added (EVA) untuk melengkapi analisis rasio keuangan [17]. Terdapat beberapa penelitian kinerja keuangan berdasar akuntansi dan kinerja keuangan berdasar pasar yang diukur dengan return saham, diantaranya penelitian oleh [18] yang meneliti pengaruh EVA terhadap return saham dan [1] yang menelti pengaruh EVA terhadap return saham pada perusahaan yang terdaftar di Jakarta Islamic Index (JII).

Penelitian tentang hubungan kinerja keuangan berdasar akuntansi dan kinerja keuangan berdasar pasar yang diukur dengan return saham telah banyak dilakukan, sementara penelitian tentang hubungan kinerja keuangan berdasar akuntansi dan kinerja keuangan berdasar pasar yang diukur dengan return saham dengan CSR sebagai variabel moderasi masih sangat jarang. Berdasarkan hal ini peneliti tertarik untuk menguji secara empiris pada perusahaan yang terdaftar di Jakarta Islamic Index (JII) karena JII merupakan salah satu indeks saham unggulan yang terdapat di BEI dengan persyaratan yang ketat, salah satunya yaitu perusahaan yang kegiatan usahanya tidak bertentangan dengan syariah seperti perjudian, riba, dan lain-lain.

\section{Landasan Teori}

\subsection{Agency Theory}

Menurut [11] teori agensi merupakan konsep yang menjelaskan hubungan kontraktual antara pihak manajemen (agent) dengan pemegang saham (principal). Principal maupun agent memiliki posisi, peran, dan kedudukan masing-masing yaitu principal sebagai pemilik modal memiliki akses pada informasi internal perusahaan sedangkan agent merupakan pelaku dalam praktek operasional perusahaan yang mempunyai informasi mengenai kinerja dan operasional secara real sehingga memungkinkan terjadinya pertentangan antara kedua pihak tersebut. Berdasarkan teori keagenan, principal sulit untuk mempercayai bahwa manajemen (agent) akan selalu bertindak berdasarkan kepentingan pemegang saham, sehingga diperlukan adanya pengawasan dari pemegang saham terhadap kinerja manajemen.

\subsection{Stakeholder Theory}

Stakeholder theory menyatakan bahwa perusahaan memiliki tanggung jawab kepada stakeholder atas 
informasi tentang bagaimana aktivitas organisasi mempengaruhi mereka. Perusahaan dalam hal ini harus memastikan bahwa hak-hak stakeholder dapat dipenuhi untuk menjaga kelangsungan hidup perusahaan [2]. Salah satu bentuk tanggung jawab tersebut yaitu melalui pengungkapan Corporate Social Responsibility (CSR) dalam laporan keuangan perusahaan, sehingga dengan adanya pengungkapan CSR oleh perusahaan diharapkan dapat memberikan sinyal untuk meningkatkan citra perusahaan yang tercermin dengan peningkatan return saham.

\subsection{Pengukuran Kinerja Keuangan berdasar}

\section{Akuntansi}

Analisis rasio keuangan merupakan pengukuran kinerja keuangan berdasar akuntansi yang sering digunakan. Selama ini analisis rasio keuangan yang digunakan terbagi menjadi empat kategori utama, yaitu rasio aktivitas, rasio profitabilitas, rasio likuiditas, dan rasio leverage [16]. Selain itu Stern Stewart \& Co, sebuah perusahaan keuangan di Amerika kemudian memperkenalkan Economic Value Added (EVA) yang dapat dijadikan dasar pengukuran kinerja keuangan perusahaan karena membuat manajer perusahaan lebih berpikir dan bertindak seperti halnya pemegang saham yaitu memilih investasi yang memaksimumkan tingkat pengembalian dan meminimumkan tingkat biaya modal sehingga nilai perusahaan dapat dimaksimumkan [5].

\subsection{Pengukuran Kinerja Keuangan Berdasar Pasar}

Kinerja keuangan berdasar pasar diukur berdasarkan tingkat return dan risiko. Menurut [9] kinerja masa lalu yang diukur menggunakan data akuntansi merupakan prediktor yang baik terhadap kinerja di masa yang akan datang yang diukur dengan menggunakan data pasar. Mereka menemukan hubungan yang signifikan antara pengukuran kinerja berdasar akuntansi dan pengukuran kinerja berdasar pasar.

Pengukuran kinerja keuangan berdasar pasar pada penelitian ini diukur dengan return saham perusahaan. Return merupakan hasil yang diperoleh dari investasi. Investor menggunakan informasi akuntansi atau pengukuran kinerja keuangan berdasar akuntansi untuk mengukur return saham yang dapat diperoleh pada masa yang akan datang. Return saham dihitung dengan rumus [6]:

$R_{:}=\frac{P_{i}-P_{: * 1}}{P_{* 1}} \times 100 \%$

Keterangan:

Rit : Total Pengembalian Saham Perusahaan ke i pada bulan $\mathrm{t}$

Pit : Harga saham periode $t$ untuk perusahaan ke i

Pit-1: Harga saham periode ke t-1 untuk perusahaan ke i

Penetapan periode harga saham dihitung dari rata-rata harga saham penutupan hari jumat setiap bulan yaitu Desember-Mei untuk setiap tahun periode pengamatan.

\subsection{Corporate Social Responsibility (CSR)}

Corporate Social Responsibility (CSR) merupakan bentuk pertanggungjawaban perusahaan kepada pemegang saham. CSR mulai digunakan sejak disahkannya Undang-Undang Nomor 40 Tahun 2007 tentang Perseroan Terbatas dan Undang-Undang Nomor 25 Tahun 2007 tentang Penanaman Modal [15]. Penelitian ini menggunakan CSR yang diukur dengan rumus:

$$
C S R I=\frac{\Sigma X_{y}}{n_{y}}
$$

\section{Keterangan:}

CSRI: Corporate Social Responsibility Disclosure Index

n $\quad$ : jumlah item untuk perusahaan $\mathrm{j}, \mathrm{nj} \leq 79$

$\mathrm{X}$ : dummy variabel: 1 = jika item i diungkapkan, 0

= jika item i tidak diungkapkan

\subsection{Jakarta Islamic Index (JII)}

Jakarta Islamic Index (JII) pertama kali diluncurkan oleh Bursa Efek Indonesia (BEI) bekerjasama dengan PT Danareksa Investment Management pada tanggal 3 Juli 2000. Saham yang masuk dalam perhitungan JII berdasarkan proses seleksi atas kinerja perdagangan 
saham syariah yang dilakukan oleh BEI yaitu (1) saham-saham yang dipilih adalah saham-saham syariah yang termasuk ke dalam DES (Daftar Efek Syariah) yang diterbitkan oleh Otoritas Jasa Keuangan (OJK) (2) saham-saham syariah tersebut kemudian dipilih 60 saham berdasarkan urutan kapitalisasi terbesar selama 1 tahun terakhir (3) dari 60 saham yang mempunyai kapitalisasi terbesar tersebut, kemudian dipilih 30 saham berdasarkan tingkat likuiditas yaitu urutan nilai transaksi terbesar di pasar regular selama 1 tahun terakhir. Jakarta Islamic Index (JII) dimaksudkan untuk digunakan sebagai tolok ukur (benchmark) untuk mengukur kinerja suatu investasi pada saham dengan basis syariah. Melalui indeks ini diharapkan dapat meningkatkan kepercayaan investor untuk mengembangkan investasi pada saham syariah. Di Bursa Efek Indonesia (BEI) terdapat Jakarta Islamic Indeks (JII) yang terdiri atas 30 saham yang memenuhi kriteria syariah yang ditetapkan Dewan Syariah Nasional (DSN). Selain itu dipertimbangkan aspek likuiditas dan kondisi keuangan perusahaan, salah satunya rasio leverage perusahaan maksimal $90 \%$.

Pengkajian ulang akan dilakukan 6 bulan sekali dengan penentuan komponen indeks pada awal bulan Januari dan Juli setiap tahunnya, sedangkan perubahan pada jenis usaha emiten akan dimonitoring secara terus menerus berdasarkan data-data publik yang tersedia [10].

\subsection{Hipotesis}

Penelitian di Indonesia lebih banyak menggunakan analisis rasio keuangan dengan return saham, seperti penelitian yang dilakukan oleh [14] menemukan bahwa ROA dan ROE secara parsial berpengaruh positif signifikan terhadap return saham. Hasil penelitian yang berbeda oleh [7] menemukan bahwa ROA berpengaruh positif dan signifikan terhadap return saham dan ROE berpengaruh negatif signifikan terhadap return saham.

[13] menemukan bahwa EVA secara parsial berpengaruh positif dan signifikan terhadap return saham pada perusahaan yang terdaftar di Jakarta Islamic Index (JII).

Berdasarkan penelitian terdahulu, masih terdapat hasil yang belum konsisten sehingga hipotesis yang diuji adalah:

Ha1: ROA berpengaruh terhadap return saham pada perusahaan yang terdaftar di Jakarta Islamic Index (JII).

Ha2: ROE berpengaruh terhadap return saham pada perusahaan yang terdaftar di Jakarta Islamic Index (JII).

Ha3: EVA berpengaruh terhadap return saham pada perusahaan yang terdaftar di Jakarta Islamic Index (JII).

Hasil penelitian yang dilakukan oleh [12] menunjukan bahwa CSR berpengaruh positif dan signifikan terhadap reaksi investor. Hasil penelitian mengenai kinerja keuangan berdasar akuntansi dan kinerja keuangan berdasar pasar serta pengungkapan CSR sebagai variabel interaksi masih berbeda antara penelitian satu dengan penelitian lainnya. Hasil penelitian yang berbeda oleh [3] menunjukkan bahwa pengungkapan CSR tidak memperkuat hubungan ROE terhadap nilai perusahaan. Berdasarkan uraian di atas, maka hipotesis yang diuji adalah:

Ha4: Pengungkapan CSR memoderasi hubungan antara ROA dan return saham pada perusahaan yang terdaftar di Jakarta Islamic Index (JII).

Ha5: Pengungkapan CSR memoderasi hubungan antara ROE dan return saham pada perusahaan yang terdaftar di Jakarta Islamic Index (JII).

Ha6: Pengungkapan CSR memoderasi hubungan antara EVA dan return saham pada perusahaan yang terdaftar di Jakarta Islamic Index (JII).

\section{Hasil Dan Pembahasan}

\subsection{Instrumen Penelitian dan Operasional Variabel}

Penelitian ini menggunakan data sekunder yang diperoleh dari Bursa Efek Indonesia (BEI), Indonesian Capital Market Directory (ICMD), yahoo finance, dan informasi dari website Bank Indonesia. Objek penelitian adalah laporan keuangan dan data pasar modal yaitu return saham perusahaan yang terdaftar dalam Jakarta Islamic Index (JII) tahun 2008-2013. 


\subsection{Populasi, Sampel dan Teknik Penarikan Sampel}

Populasi perusahaan dalam penelitian ini adalah perusahaan-perusahaan yang terdaftar dalam Jakarta Islamic Index (JII) periode terdaftar Desember-Mei selama tahun 2008-2013. Setelah dilakukan pengumpulan data kemudian dilakukan penarikan sampel dengan menggunakan purposive sampling yaitu berdasarkan kriteria sesuai dengan syarat yang telah ditentukan yaitu perusahaan yang terdaftar selama 5 tahun tersebut dan perusahaan yang mengungkapkan CSR dalam laporan keuangan perusahaan maka diperoleh sampel sebanyak 19 perusahaan dengan jumlah observasi 95 data perusahaan.

\subsection{Analisis Data}

Data dianalisis menggunakan Eviews 7 dan IBM Statistic SPSS 20. Analisis regresi data panel dan uji Asumsi Mutlak digunakan untuk menganalisis bagaimana pengaruh kinerja keuangan berdasar akuntansi dan kinerja keuangan berdasar pasar serta apakah CSR mampu memoderasi hubungan kinerja keuangan berdasar akuntansi dan kinerja keuangan berdasar pasar pada perusahaan yang terdaftar di Jakarta Islamic Index (JII). Model persamaan regresi dinyatakan sebagai berikut:

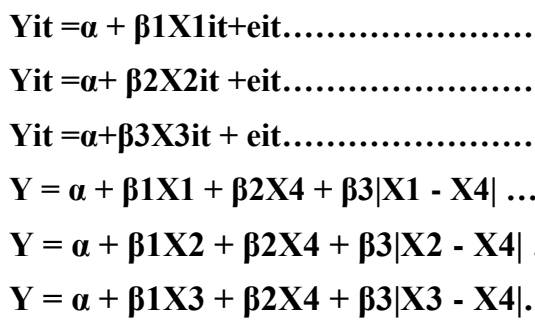

Keterangan:

$\mathrm{Y}=$ Return saham

$\alpha=$ Konstanta

$$
\mathrm{X} 1 \text { = Return On Asset (ROA) }
$$

$\mathrm{X} 2$ = Return On Equity (ROE)

X3 = Economic Value Added (EVA)

X4 = Corporate Social Responsibility (CSR)

$\mid \mathrm{X} 1$ - X4| = Interaksi antara ROA dan CSR yang diukur dengan nilai absolut

$\mid \mathrm{X} 2$ - X4| = Interaksi antara ROE dan CSR yang diukur dengan nilai absolut

$\mid \mathrm{X} 3$ - X4|= Interaksi antara EVA dan CSR yang diukur dengan nilai absolut

\section{Tabel 1. Analisis Regresi Model 1}

\begin{tabular}{|c|c|c|c|c|}
\hline \multicolumn{5}{|c|}{$\begin{array}{l}\text { Dependent Variable: RS } \\
\text { Method: Pooled EGLS (Cross- } \\
\text { Date: 08/25/15 Time: } 20: 19 \\
\text { Sample: } 2008 \text { } 2012 \\
\text { Included observations: } 95 \\
\text { Cross-sections included: } 19\end{array}$} \\
\hline Variable & Coefficient & Std. Error & t-Statistic & Prob. \\
\hline C & 0.170111 & 0.002297 & 74.07175 & 0.0000 \\
\hline ROA & 0.075287 & 0.008889 & 8.469997 & 0.0000 \\
\hline \multicolumn{5}{|c|}{ Weighted Statistics } \\
\hline R-squared & 0.038638 & \multirow{5}{*}{\multicolumn{2}{|c|}{$\begin{array}{l}\text { Mean dependent var } \\
\text { S.D. dependent var } \\
\text { Sum squared resid } \\
\text { Durbin-Watson stat }\end{array}$}} & 0.183579 \\
\hline Adjusted R-squared & 0.114105 & & & 0.071425 \\
\hline S.E. of regression & 0.070051 & & & 8.847683 \\
\hline F-statistic & 72.46429 & & & 1.797833 \\
\hline Prob(F-statistic) & 0.000000 & & & \\
\hline
\end{tabular}

Berdasarkan tabel 1 di atas, Adjusted R Square memiliki nilai 0,114105 . Hal ini berarti return saham perusahaan dapat dijelaskan sebesar $11,4 \%$ oleh variabel ROA, sedangkan sisanya $(100 \%-11,4 \%=$ $88,6 \%$ ) dijelaskan oleh variabel lain. Variabel ROA memiliki nilai signifikansi lebih kecil dari 0.05, maka disimpulkan bahwa kinerja keuangan berdasar akuntansi yang diukur dengan ROA berpengaruh terhadap kinerja keuangan berdasar pasar yang diukur dengan return saham, sehingga Hal dapat didukung atau diterima.

\section{Tabel 2. Analisis Regresi Model 2}

Dependent Variable: RS01

Method: Pooled EGLS (Cross-section random effects)

Date: 08/25/15 Time: $20: 24$

Sample: 20082012

Included observations: 95

Cross-sections included: 19

\begin{tabular}{|c|c|c|c|c|}
\hline Variable & Coefficient & Std. Error & t-Statistic & Prob. \\
\hline C & 0.171081 & 0.002401 & 71.24836 & 0.0000 \\
\hline ROE & 0.043738 & 0.006052 & 7.227231 & 0.0000 \\
\hline \multicolumn{5}{|c|}{ Weighted Statistics } \\
\hline $\mathrm{R}$ - squared & 0.028430 & \multicolumn{2}{|c|}{ Mean dependent var } & 0.183579 \\
\hline Adjusted R-squared & 0.117891 & \multicolumn{2}{|c|}{ S.D. dependent var } & 0.071425 \\
\hline S.E. of regression & 0.070422 & \multirow{2}{*}{\multicolumn{2}{|c|}{$\begin{array}{l}\text { Sum squared resid } \\
\text { Durbin-Watson stat }\end{array}$}} & 8.941629 \\
\hline F- statistic & 52.75959 & & & 1.795988 \\
\hline Prob(F-statistic) & 0.000000 & & & \\
\hline
\end{tabular}

Berdasarkan tabel 2 di atas, Adjusted R Square memiliki nilai 0,117891. Hal ini berarti return saham perusahaan dapat dijelaskan sebesar $11,7 \%$ oleh variabel ROE, sedangkan sisanya $(100 \%-11,7 \%=$ $88,3 \%$ ) dijelaskan oleh variabel lain. Variabel ROE 
memiliki nilai signifikansi lebih kecil dari 0.05, maka disimpulkan bahwa kinerja keuangan berdasar akuntansi yang diukur dengan ROE berpengaruh terhadap kinerja keuangan berdasar pasar yang diukur dengan return saham, sehingga $\mathrm{Ha} 2$ dapat didukung atau diterima.

\section{Tabel 3. Analisis Regresi Model 3}

Dependent Variable: RS02

Method: Pooled EGLS (Cross-section random effects)

Date: 08/25/15 Time: 20:33

Sample: 20082012

Included observations: 95

Cross-sections included: 19

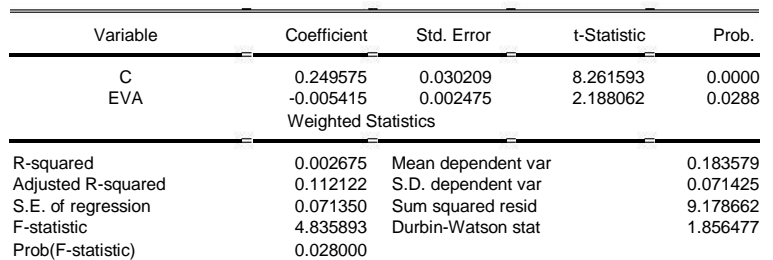

Berdasarkan tabel 3 di atas, Adjusted R Square memiliki nilai 0,112122 . Hal ini berarti return saham perusahaan dapat dijelaskan sebesar $11,2 \%$ oleh variabel EVA, sedangkan sisanya $(100 \%-11,2 \%=$ $88,8 \%$ ) dijelaskan oleh variabel lain. Variabel EVA memiliki nilai signifikansi lebih kecil dari 0.05, maka disimpulkan bahwa kinerja keuangan berdasar akuntansi yang diukur dengan EVA berpengaruh terhadap kinerja keuangan berdasar pasar yang diukur dengan return saham, sehingga $\mathrm{Ha} 3$ dapat didukung atau diterima.

Tabel 4. Analisis Regresi Model 4

\begin{tabular}{|c|c|c|c|c|c|c|}
\hline & \multicolumn{6}{|c|}{ Coefficients $^{\mathrm{a}}$} \\
\hline & & \multicolumn{2}{|c|}{ Unstandardized Coefficients } & \multirow{2}{*}{$\begin{array}{c}\begin{array}{c}\text { Standardized } \\
\text { Coefficients }\end{array} \\
\text { Beta }\end{array}$} & \multirow[t]{2}{*}{$\mathrm{t}$} & \multirow[t]{2}{*}{ Sig. } \\
\hline & & B & Std. Error & & & \\
\hline \multirow{4}{*}{1} & (Constant) & .208 & .039 & & 5.802 & .000 \\
\hline & Zscore(ROA) & .008 & .055 & .039 & .151 & .882 \\
\hline & Zscore(CSR) & .021 & .024 & 277 & .897 & .385 \\
\hline & AbsX1_X2 & -.042 & .035 & -.377 & -1.209 & .247 \\
\hline
\end{tabular}

Berdasarkan tabel 4 di atas, menunjukkan nilai signifikansi lebih besar dari 0.05, maka disimpulkan bahwa variabel ZROA, ZCSR dan AbsX1_X2 tidak mampu memoderasi hubungan kinerja keuangan berdasar akuntansi dan kinerja keuangan berdasar pasar yang diukur dengan return saham, sehingga Ha4 tidak dapat didukung atau diterima.
Tabel 5. Analisis Regresi Model 5

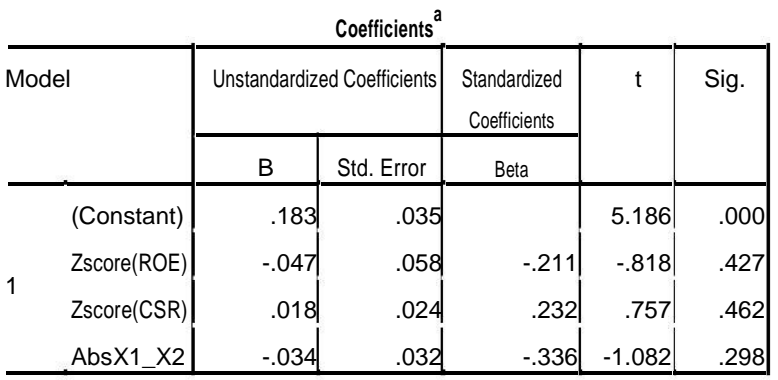

a. Dependent Variable: RS

Berdasarkan tabel 5 di atas, menunjukkan nilai signifikansi lebih besar dari 0.05, maka disimpulkan bahwa variabel ZROE, ZCSR dan AbsX1_X2 tidak mampu memoderasi hubungan kinerja keuangan berdasar akuntansi dan kinerja keuangan berdasar pasar yang diukur dengan return saham, sehingga Ha5 tidak dapat didukung atau diterima.

Tabel 6. Analisis Regresi Model 6

\begin{tabular}{|c|c|c|c|c|c|c|}
\hline \multicolumn{7}{|c|}{ Coefficients $^{a}$} \\
\hline \multicolumn{2}{|c|}{ Model } & \multicolumn{2}{|c|}{ Unstandardized Coefficients } & \multirow{2}{*}{$\begin{array}{c}\begin{array}{c}\text { Standardized } \\
\text { Coefficients }\end{array} \\
\text { Beta }\end{array}$} & \multirow[t]{2}{*}{$\mathrm{t}$} & \multirow[t]{2}{*}{ Sig. } \\
\hline & & $\mathrm{B}$ & Std. Error & & & \\
\hline \multirow{4}{*}{1} & (Constant) & .218 & .025 & & 8.593 & .000 \\
\hline & Zscore(EVA & -.008 & .015 & -.125 & -.540 & .598 \\
\hline & Zscore (CSR & .004 & .018 & .053 & .227 & .824 \\
\hline & AbsX1_X2 & -.037 & .015 & -.549 & -2.484 & .056 \\
\hline
\end{tabular}

a. Dependent Variable: RS

Berdasarkan tabel 6 di atas, menunjukkan nilai signifikansi lebih besar dari 0.05, maka disimpulkan bahwa variabel ZEVA, ZCSR dan AbsX1_X2 tidak mampu memoderasi hubungan kinerja keuangan berdasar akuntansi dan kinerja keuangan berdasar pasar yang diukur dengan return saham, sehingga $\mathrm{Ha} 6$ tidak dapat didukung atau diterima.

\section{Kesimpulan}

Dari hasil penelitian ini, kinerja keuangan berdasar akuntansi yang diukur dengan ROA, ROE, dan EVA berpengaruh terhadap kinerja keuangan berdasar akuntansi yang diukur dengan return saham, sedangkan variabel CSR tidak mampu memoderasi hubungan kinerja keuangan berdasar akuntansi dengan kinerja 
keuangan berdasar pasar yang diukur dengan return saham. Keterbatasan dalam penelitian ini adalah periode dan sampel yang digunakan dalam penelitian ini kurang cukup menunjukkan hasil yang baik. Selain itu beberapa data laporan keuangan tidak dapat diperoleh sehingga mengurangi jumlah sampel yang diteliti, maka diharapkan keterbatasan ini dapat menjadi masukan dan pertimbangan yang baik untuk penelitian selanjutnya.

Saran untuk penelitian selanjutnya yaitu sebaiknya menambah lagi periode penelitian sehingga menambah jumlah sampel perusahaan yang akan diteliti dan diharapkan menggunakan semua jenis perusahaan syariah yang telah terdaftar di BEI dan masuk dalam Index Saham Syariah Indonesia (ISSI) serta perlu menambah rasio-rasio keuangan lainnya yang mengukur profitabilitas dan likuiditas yang sekiranya diduga memiliki pengaruh terhadap return saham.

\section{Daftar Referensi}

I. Berakon, “ Analisis Pengaruh Economic Value Added, Market Value Added, dan Return On Investmen Terhadap Return Saham Pada Perusahaan yang Terdaftar di Jakarta Islamic Index (JII)", Yogyakarta, hal 67, 2012.

R. E. Freeman, Strategic Management: A

Stakeholder Approach. Cambridge University Press, page 72-85, 2010.

N. I. Febriana, "Pengaruh Return On Equity

Terhadap Nilai Perusahaan Dengan Pengungkapan Corporate Social Responsibility Sebagai Variabel Pemoderasi Pada PerusahaanPerusahaan Dalam Jakarta Islamic Index (JII) Periode 2009-2011”, hal 56-62, 2013.

T.A. Gumanti, Manajemen Investasi Konsep, Teori dan Aplikasi. Jember: Mitra Wacana Media, 2011. Hal 145 .

M. M. Hanafi, Manajemen Keuangan Edisi 1. Yogyakarta: BPFE, hal 213-215, 2004.

J. Hartono, Teori Portofolio dan Analisis Investasi. Yogyakarta: BPFE, hal 345, 2010.

L. Hasanah, “Analisis Pengaruh Leverage Keuangan dan Rasio Profitabilitas Terhadap
Return Saham Pada Perusahaan yang Terdaftar di Jakarta Islamic Index/JII Tahun 2005-2007”, hal 85, 2008.

B. Hidayat, Perkembangan Investasi di Indonesia 5 Tahun Terakhir. Jakarta: 2012. Hal 7.

R. E. Hoskisson, R. A. Johnson, and D. D. Moesel, JstorThe Academy of Management Journal. Retrieved Januari2015,3,fromJstor:http://www.jstor.org/dis cover/10.2307/256671?sid=21105722985283\&ui $\mathrm{d}=4 \&$ uid=2, 1994 .

IDX Indonesia Stock Exchange, Retrieved

Desember

2014,fromidx:http://www.idx.co.id/idid/beranda/ informasi/bagiinvestor/indeks.aspx, 2010.

M. C. Jensen, Foundations of Organizational Strategy. Harvard University Press, page 112, 2001.

A. Listyanti, "Pengaruh Pengungkapan Tanggung Jawab Sosial Perusahaan Terhadap Reaksi Investor: Studi Pada Perusahaan Manufaktur yang Terdaftar di Bursa Efek Indonesia Periode Tahun 2008-2009”, hal 14, 2011.

L. Marini, "Analisis Pengaruh Economic Value Added (EVA), Return On Equity (ROE) dan Arus Kas Operasi Terhadap Return Saham Pada Perusahaan-Perusahaan yang Terdaftar di Jakarta Islamic Index (JII) Periode 20032006", hal 10, 2008.

S.Ngaisah, "Pengaruh Rasio Profitabilitas dan Leverage Terhadap Return Saham Pada Perusahaan yang Terdaftar di Jakarta Islamic Index Tahun 2004-2006”, hal 45, 2008.

Prokum Kementrian Energi dan Sumber Daya Mineral, Retrieved Desember 24, 2014, from Kementrian Energi dan Sumber Daya Mineral Web Site: http://prokum.esdm.go.id/uu/2007/uu-402007.pdf, 2007.

R. A. Sartono, Manajemen Keuangan Teori dan Aplikasi Edisi 4. Yogyakarta: BPFE Yogyakarta, hal 78, 2001.

R. F. Simbolon, M. Dzulkirom, dan M. Saifi, "Analisis EVA (Economic Value Added) Untuk Menilai Kinerja Keuangan Perusahaan (Studi 
Pada Perusahaan Farmasi Pada Bursa Efek

Indonesia Periode 2010-2012)”, Jurnal

Administrasi Bisnis (JAB) Vol. 8 No. 1, 1-8, 2014.

H. Sunardi, "Pengaruh Penilaian Kinerja dengan ROI dan

EVA terhadap Return Saham pada Perusahaan

yang Tergabung dalam Indeks LQ 45 di Bursa

Efek Indonesia”. Jurnal Akuntansi , 70-92, 2010. 